\title{
THE HAPLOID EMBRYOIDS DEVELOPMENT IN ANTHER CULTURE OF TRANSFORMED TOBACCO (NICOTIANA TABACUM L. )
}

\author{
JAROSLAVA DUBOVÁ \\ Department of Plant Physiology and Anatomy, \\ Faculty of Science, Masaryk University, Kotlárská 2, \\ CZ-611 37 Brno, Czech Republic
}

\begin{abstract}
Induction of pollen embryogenesis was used for the test of cytokinin influence on the development of pollen grain. Gene for maize cytokinin-specific $\beta$-glucosidase were introduced into tobacco genome together with the methotrexate resistance marker (Brzobohatý et al. 1994). Anther culture of T1 generation of transformed Nicotiana tabacum L. plants revealed that high activity of $\beta$-glucosidase caused a reduced regeneration of pollen embryoids. The stages of pollen embryoid development were comparable with those of zygotic embryos. Optimal nutritive medium contained charcoal and chelated iron. The absence of iron in the initiation medium caused a distinct decrease of pollen embryoid regeneration.
\end{abstract}

KEY WORDS: Nicotiana tabacum, anther culture, pollen embryogenesis, $\beta$-glucosidase transformants, charcoal.

\section{INTRODUCTION}

Plant hormones regulating basic developmental processes are often conjugated with various low molecular substances as sugars and amino acids to set inactive forms. Active forms of hormones are released from these conjugates by specific enzymes (Schliemann 1991). Brzobohatý et al. (1993) have cloned c DNA, Zm-p60.1, coding a novel maize cytokininspecific $\beta$-glucosidase. The $\mathrm{Zm}$-p60.1 $\beta$-glucosidase has been shown to release free cytokinins from their O-and $\mathrm{N}-3$-glucosides both in vitro and in vivo. Recently, transgenic tobacco plants (Nicotiana tabacum L.) were constructed for study of $\mathrm{Zm}$-p60.1 effects on equilibrium between free and conjugated cytokinins, and for evaluation of a feasibility of cytokinin release from its inactive conjugates. A methotrexate resistance marker is present on the T-DNA and co-segregates with the $\beta$-glucosidase activity. The level of free cytokinins was higher in older than in young leaves of these transgenic tobacco plants expressing Zm-p60.1 constitutively. The higher levels of cytokinins in older leaves represent a reverse of normal cytokinin gradient in plant (Brzobohatý et al. 1994).

Cytokinins may have an important role in regulation of pollen development. It has been proposed that a nuclear restorer gene for cytoplasmic male sterility in barley acts by altering cytokinin metabolism. In addition, cytokinins have been used in some plant species as gametocides (Kaul 1988). A changed segregation was found in one transgenic plant (T7) showing high Zm-p60.1 activity. A half of offspring was resistant to methotrexate following pollination with pollen from nontransformed plants. No methotrexate resistant offspring were identified when T7 was used as a pollen parent in cross with non-transformed plant. Thus, pollen that carries the T-DNA changed its biological activity (Brzobohatý, personal commu- nication 1994). With respect to the ability of $\beta$-glucosidase to split cytokinin conjugates, we have expected conspicuous differences between regeneration capability in anther culture of transformed and control plants. In addition, the experiments were performed to obtain the homozygous plants expressing high Zm-p60.1 activity,

\section{MATERIAL AND METHODS}

Day neutral tobacco (Nicotiana tabacum L.cv. Petit Havana SR1) was used for experiments. The seeds of T1 generation derived by self-pollination of primary transformants were obtained from laboratory of Dr. Brzobohatý. Plants were grown in field conditions. Flower buds for anther culture were collected at the uninuclear stage of microspores. Isolated anthers were plated on the Nitsch medium (Nitsch 1969) with 0,7\% agar, IAA $\left(0.1 \mathrm{mgl}^{-1}\right)$ and charcoal $\left(0\right.$ or $\left.500 \mathrm{mgl}^{-1}\right)$. Culture media were adjusted to $\mathrm{pH} 5.8$ prior sterilisation by autoclaving. All cultures were incubated in growth chamber under fluorescent illumination (approximately $50 \mu \mathrm{mol} \cdot \mathrm{m}^{-2} \cdot \mathrm{s}^{-1}, 16-\mathrm{h}$ light period, $26^{\circ} \mathrm{C}$ day, $22^{\circ} \mathrm{C}$ night).

In our experiments we have tested: i/ the influence of $\beta$-glucosidase activity on regeneration capacity of anthers; ii/ the influence of charcoal in the initiation medium on anther regeneration capacity; iii/ a control of the embryoid development by the chelated iron absence in the first stage of culture as was referred by Vagera et al. (1979).

The total number of 4.000 anthers was cultured in all experiments. A part of regenerated plants (2.466) was selected on the Murashige et Skoog medium (Murashige et Skoog 1962) without growth regulators and with methotrexate $\left(0.1-0.5 \mathrm{mgl}^{-1}\right)$. The expression of the introduced gene was estimated bioche- 

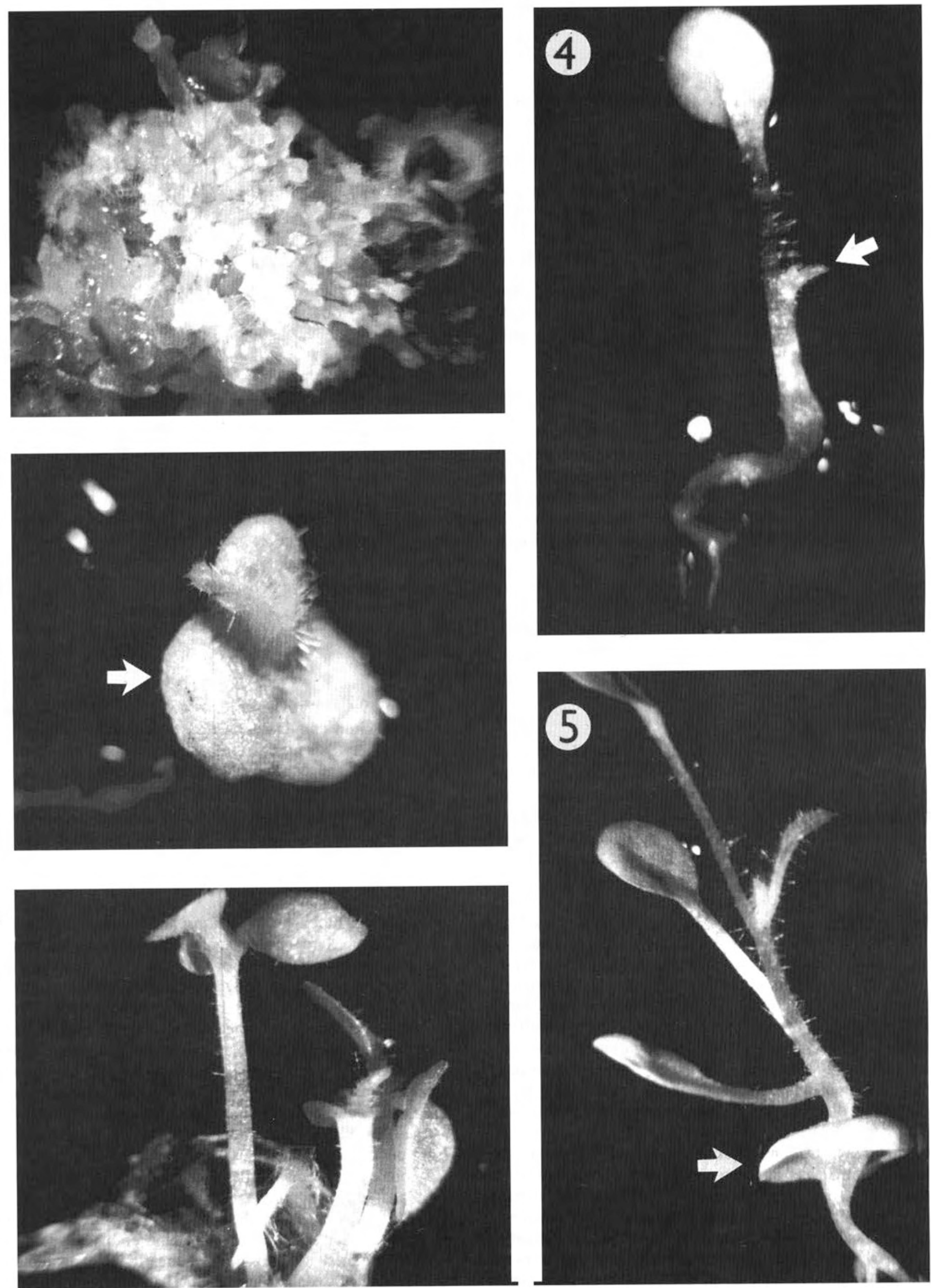

Figs 1-5. Fig. 1. An anther with embryoids, 4 weeks of culture, x 15.

Fig. 2. Apex of plantlet arising from joint cotyledon (arrow), 8 weeks of culture, $x 23$.

Fig. 3. Fully developed plantlets on the anther, 5 weeks of culture, $x 25$.

Fig. 4. Plantlet with asynchronously arised cotyledons. Arrow indicates delayed development of the second cotyledon, 8 weeks of culture, $x 15$.

Fig. 5. Developed plantlet with joint cotyledons (arrow), 8 weeks of culture, $x 15$. 
mically in both mother plants and selected pollen regenerants. Protein extract from leaves was incubated with 4-nitrophenyl$\beta$, D-glucopyranosid as a substrate and the amount of hydrolysed nitrophenyl was measured by a Specol 11 spectrophotometer. Chromosomes in root tip cells were stained by lactopropionic-orcein. Dihaploidisation of haploid plants was induced by colchicine treatment of nodal segments.

\section{RESULTS}

Isolated anthers changed their colour subsequently from green and yellow to brown throughout three weeks of culture. First small globules were observed in dehisced anthers following two weeks of culture. Multicellular globular embryoids were differentiated subsequently into heart, torpedo and cotyledonary stages. The development of pollen embryoids was morphologically similar to the zygotic embryogenesis. There was a great range of frequency of regenerated embryoids in one anther (from 1 to 108). We observed various morphological aberrations similar to those referred by Stolarz et al. (1991), especially in anthers with more frequent regeneration. The plants with long part of hypocotyl and root, but with the cotyledons arrested at a stage characteristic for the heart-shaped or torpedo-shaped embryo were the most frequent aberration (Fig. 1). The plantlets were normally and more advanced developed when a reduced regeneration occurred on the anther (Fig. 3). The joint trumpet-like cotyledons (Figs 2, 5) or unsynchronous development of cotyledons (Fig. 4) were seen, too. Despite these abnormalities, almost all embryoids were able to form complete, haploid plantlets (Fig. 5).

Higher activity of $\beta$-glucosidase in mother plant did not unambiguously influence the frequency of regenerating anthers (Table 1., Fig. 6). Dehisced anther containing at least one embryoid or one growing plantlet was classified as productive anther according to Vagera et al. (1979). Fig. 6 describes the comparison of the relative amounts of the so-called productive anthers from both transformed and control plants. Plants 2-T3, 2-T4 and 2-T5 had very similar ratio of productive anthers. It was observed among various lines as well as when we compared transformed and control plants. On the other hand, a distinct decrease of regeneration capacity was found in $\mathrm{T} 7\left(\mathrm{~T}^{+}\right)$anthers.

TABLE 1. Influence of $\beta$-glucosidase activity on androgenesis of tobacco.

\begin{tabular}{cc|c|c|c}
\hline \multicolumn{2}{c|}{ Plant } & $\begin{array}{r}\text { Isolated } \\
\text { anthers }\end{array}$ & $\begin{array}{c}\text { Productive } \\
\text { anthers }\end{array}$ & $\%$ \\
\hline 2-T3 & T+ & 273 & 87 & 31.9 \\
2-T3 & T- & 54 & 16 & 29.6 \\
2-T4 & T+ & 119 & 58 & 48.7 \\
2-T4 & T- & 125 & 44 & 35.2 \\
2-T5 & T+ & 234 & 90 & 38.5 \\
2-T5 & T- & 0 & 0 & 0 \\
1-T7 & T+ & 95 & 11 & 11.6 \\
2-T7 & T+ & 83 & 6 & 7.2 \\
2-T7 & T- & 84 & 20 & 23.8 \\
\hline \multicolumn{2}{r|}{ Total } & 1067 & 332 & \\
\hline
\end{tabular}

The regeneration ability of anthers was conspicuously influenced by the presence of charcoal in the initiation medium (Table 2, Fig. 7). Anthers which were cultured in the first phase on the medium with charcoal provided several times
TABLE 2. Influence of charcoal on the androgenesis of tobacco.

\begin{tabular}{|c|c|c|c|c|}
\hline \multicolumn{2}{|c|}{ Plant } & \multirow{2}{*}{$\begin{array}{c}\begin{array}{c}\text { Isolated } \\
\text { anthers }\end{array} \\
158\end{array}$} & \multirow{2}{*}{$\begin{array}{c}\text { Productive } \\
\text { anthers }\end{array}$} & \multirow{2}{*}{$\begin{array}{r}\% \\
41.77\end{array}$} \\
\hline 2-T3 & $+\mathrm{C}$ & & & \\
\hline 2-T3 & $-\mathrm{C}$ & 169 & 37 & 21.89 \\
\hline 2-T4 & $+\mathrm{C}$ & 145 & 83 & 57 \\
\hline $2-\mathrm{T} 4$ & $-\mathrm{C}$ & 99 & 19 & 19.19 \\
\hline $2-\mathrm{T} 5$ & $+\mathrm{C}$ & 175 & 85 & 49 \\
\hline 2-T5 & $-\mathrm{C}$ & 59 & 5 & 8 \\
\hline $1-\mathrm{T} 7$ & $+\mathrm{C}$ & 30 & 5 & 17 \\
\hline 1-T7 & $-\mathrm{C}$ & 65 & 6 & 22 \\
\hline $2-\mathrm{T} 7$ & $+\mathrm{C}$ & 99 & 22 & 22 \\
\hline $2-\mathrm{T} 7$ & $-\mathrm{C}$ & 68 & 4 & 6 \\
\hline \multicolumn{2}{|c|}{ Total } & 1067 & 332 & \\
\hline
\end{tabular}

higher amount of productive anthers then anthers cultured without charcoal.

The absence of chelated iron in initiation medium had deleterious effect on the regeneration capacity of anthers (Table 3., Fig. 8).

TABLE 3. Regeneration of anthers on iron free medium.

\begin{tabular}{c|c|c|c|c|c}
\hline Plant & $\begin{array}{c}\text { Isolated } \\
\text { anthers }\end{array}$ & Infection & $\begin{array}{c}\text { Estimated } \\
\text { anthers }\end{array}$ & $\begin{array}{c}\text { Productive } \\
\text { anthers }\end{array}$ & $\%$ \\
\hline 4-T3 & 813 & 306 & 507 & 11 & 2.1 \\
4-T4 & 639 & 191 & 448 & 17 & 3.8 \\
4-T5 & 680 & 187 & 493 & 12 & 2.4 \\
4-T7 & 754 & 375 & 379 & 17 & 4.5 \\
\hline Total & 2886 & 1059 & 1827 & 57 & \\
\hline
\end{tabular}

Regenerated embryoids and plantlets on anthers were scored and then about 2.500 of plantlets were subcultured on the selection medium with methotrexate. Plantlets which did not inherit the T-DNA subsequently stopped their growth, lost photosynthetic pigments, and then get brown and died. The vitrification of sensitive plants was also frequently observed. The survey of selection step is demonstrated on the Table 4 . The regenerants from anthers of 2-T3, 2-T4 and 2-T5 plants with higher $\beta$-glucosidase activity were selected in 28,20 and $22 \%$, respectively. We obtained no resistant plant in 1-T7 as well as (T-)2-T7 anthers. It was surprising that several plants in which we have not expected T-DNA (that means regenerants of plants with very low activity of $\beta$-glucosidase and T7 regenerants) were able to growth on methotrexate. Furthermore, haploid number of chromosomes in these plants confirmed their pollen origin. The T7 regenerants with the ability to grow on methotrexate had markedly changed their habitus. The plantlets had reduced apical dominance, their leaves were small and narrow, and development of their roots was strongly inhibited.

Higher activity of $\beta$-glucosidase was found in $81.4 \%$ of regenerants following methotrexate selection. The rate of haploids in the population of regenerants was $91,2 \%$.

Colchicine treatment of haploid plant segments led to dihaploidization, and the seeds of self-pollinated flowers were collected for further experiments. 
TABLE 4. Selection on the medium with methotrexate.

\begin{tabular}{|c|c|c|c|c|c|}
\hline \multicolumn{5}{|c|}{ Regenerated plants from anthers of plants expressing high $\beta$-glucosidase activity } & \multirow{2}{*}{$\begin{array}{l}(\mathrm{T}+) \\
2-\mathrm{T} 7\end{array}$} \\
\hline Plants & 2-T3 & 2-T4 & 2-T5 & $1-\mathrm{T} 7$ & \\
\hline Cultured & 285 & 686 & 290 & 155 & 110 \\
\hline Selected & 235 & 138 & 65 & 0 & 16 \\
\hline$\%$ & 28.8 & 20.1 & 22.6 & 0 & 14.5 \\
\hline \multicolumn{5}{|c|}{ Regenerated plants from anthers of plants expressing low $\beta$-glucosidase activity } & (T-) \\
\hline Cultured & 10 & 238 & 0 & 0 & 66 \\
\hline Selected & 6 & 14 & 0 & 0 & 0 \\
\hline$\%$ & 60 & 5.9 & 0 & 0 & 0 \\
\hline
\end{tabular}

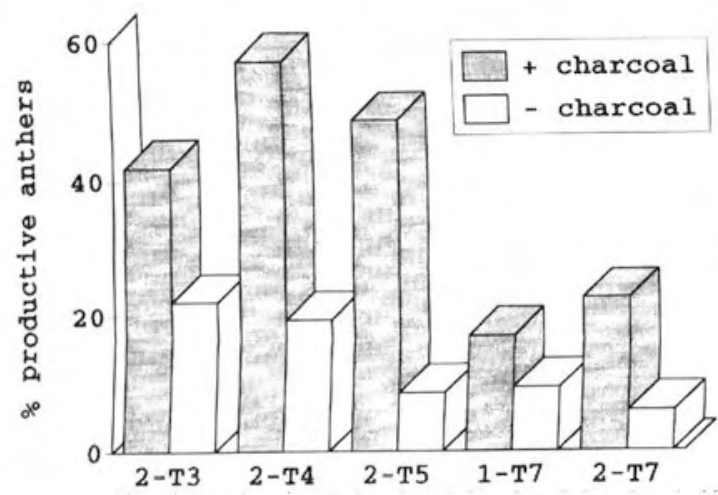

Fig. 6. Influence of $\beta$-glucosidase activity on androgenesis of tobacco.

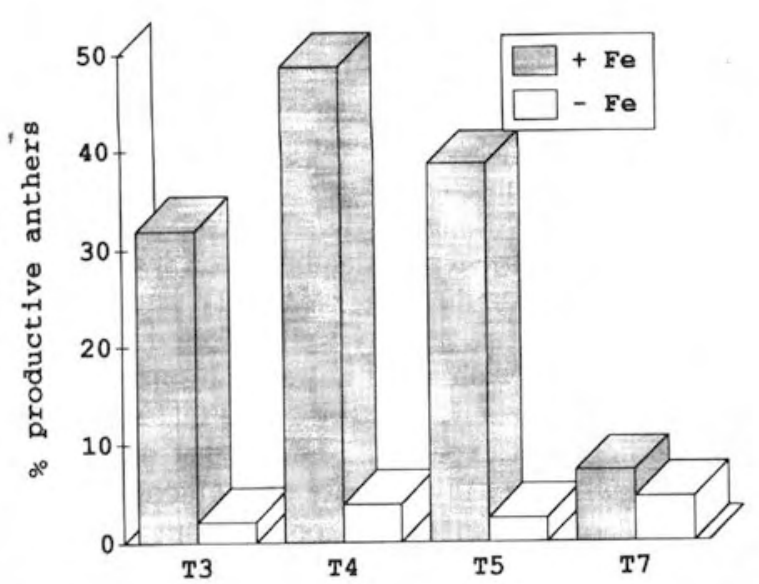

Fig. 8. Influence of $\mathrm{Fe}$ in initiation medium on androgenesis of tobacco.

\section{DISCUSSION}

The evaluation of anther culture tests has revealed diminished viability of the pollen from T7 plants which expressed the highest activity of $\beta$-glucosidase. The T7 pollen regenerants - similarly as in crossing experiments (Brzobohatý, personal communication 1994) - were not bearing the resistance

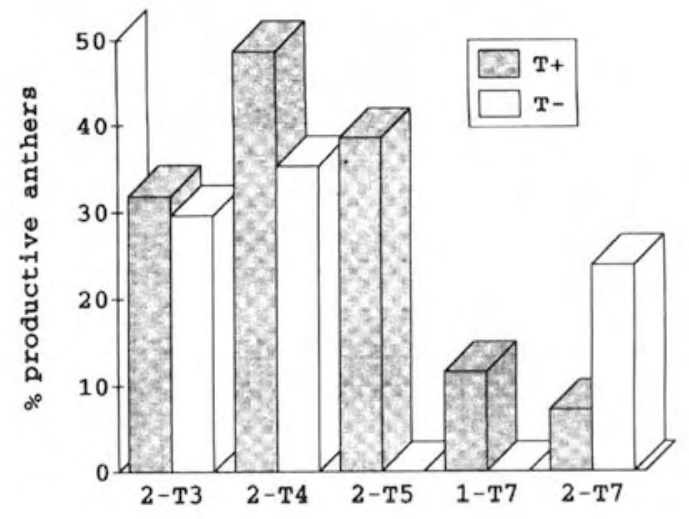

Fig. 7. Influence of charcoal on androgenesis of transformed tobacco.

Figs 6-8 illustrate the comparison of relative amounts of the so-called productive anthers. Anthers from plants with high $\beta$-glucosidase activity are marked as $\mathrm{T}+$, anthers from control plants as T-. Presence or absence of either charcoal or iron in the initiation medium is marked as + or -. Symbols under abscise indicate various lines of T1 generation of transformants.

to methotrexate excluding several abnormal plants. This phenomenon could be explained by a mutation or presence of an extremely strong enhancer.

We have confirmed a promotion of charcoal like to growth and rooting in vitro as it was described by Von Arnold (1982), Bon et al. (1988). The promotive effect of charcoal is usually explained by its ability to bind organic compounds or 
toxins excreted by cultured tissues. The effects of phenolamines naturally presented in charcoal (Bon et al. 1988) and the ability to keep pH value in the medium (Owen et al. 1991) are another explanations.

We have never seen accumulation of globular embryoids in anthers cultured on iron free medium as described by Vagera et al. (1979) and Stolarz et al. (1991). The regeneration capacity of anthers was conspicuously decreased on the iron-omitted medium and was not restored after anther subculture to the iron-supplemented medium.

\section{CONCLUSION}

Our findings of decreased regeneration capacity of pollen from $\mathrm{T} 7$ plants suggest that high $\beta$-glucosidase activity blocks the development of pollen. This block of development is probably situated early in microsporogenesis that could influence both the way of pollen development to mature pollen grain and the pollen embryogenesis.

\section{ACKNOWLEDGEMENTS}

Naděžda Paráková is acknowledged for skilful technical assistance.

This work was the part of the 204-93-0350 project supported by the GA ČR.

\section{LITERATURE CITED}

BON M.C., GENDRAUD M., FRANCLET A., 1988. Roles of phenolic compounds on micropropagation of juvenile and mature clones of Sequoiadendron giganteum: Influence of activated charcoal. Sci. Hort. 34: 283-291.

BRZOBOHATÝ B., MOORE I., KRISTOFFERSEN P., BAKO L., CAMPOS N., SHELL J., PALME K., 1993. Release of active cytokinin by a $\beta$-glucosidase localized to the maize root meristem. Science 262: 1081-1084.

BRZOBOHATÝ B., MACHÁČKOVÁ I., BENKOVÁ E., SCHELL J., PALME K., 1994. A maize $\beta$-glucosidase acting preferentially on cytokinin-glucosides can influence free cytokinin levels when expressed in transgenic tobacco plants. 22nd Aharon Katzin-Katchalski Conf.: Plant Mol. Biology - Potential Impact on Agriculture and the Environment, Köln, Germany, 2-6 October 1994: 74.

KAUL M.L.H., 1988. Male sterility in higher plants. Springer-Verlag, Berlin.

MURASHIGE T., SKOOG F., 1962. A revised medium for rapid growth and bioassays with tobacco tissue cultures. Physiol. Plant. 15: 472-497.

NITSCH J. P., 1969. Experimental androgenesis in Nicotiana. Phytomorphology 19: 389- 404.

OWEN H.R., WENGERD D., MILLER A.R., 1991. Culture medium $\mathrm{pH}$ is influenced by basal medium, carbohydrate source, gelling agent, activated charcoal, and medium storage method. Plant Cell Rep. 10: 583-586.

VAGERA J., HAVRÁNEK P., OPATRNÝ Z., 1979. Regulation of in vitro androgenesis of tobacco: Relationship between concentration of iron ions and kinetin. Biochem. Physiol. Pflanzen 174: 752-760.

VON ARNOLD S., 1982. Factors influencing formation, development and rooting of adventitious shoots from embryos of Picea abies $\mathrm{L}$. Karst. Plant Sci. Lett. 27: 275-287.

SCHLIEMANN W., 1991. Zum Konzept der reversiblen Konjugation bei Phytohormonen. Naturwiss. 78: 392-401.

STOLARZ A., MACEWICZ J., LÖRZ H. 1991. Direct somatic embryogenesis and plants regeneration from leaf explants of Nicotiana tabacum L. J. Plant Physiol. 137: 347-357.

\section{ROZWÓJ HAPLOIDALNYCH EMBRIOIDÓW Z HODOWLI PRĘCIKÓW TRANSFORMOWANEGO TYTONIU}

\section{STRESZCZENIE}

Pobudzenie embriogenezy pyłku zostało przyjęte jako sprawdzian wpływu cytokinin na rozwój ziarna pyłku. Gen, cytokinino-specyficznej $\beta$-glukozydazy kukurydzy został wprowadzony do genomu tytoniu wraz z markerem methotrexate odporności. Hodowle tkankowe pokolenia T1 transformowanego tytoniu wskazują że wysoki poziom aktywności $\beta$-glukozydazy powoduje zmniejszenie pojawiania się pyłkowych embrioidów. Etapy rozwojowe pyłkowych zarodków są podobne jak w zarodkach zygotycznych. Optymalna dla rozwoju zarodków pożywka zawierała węgiel aktywny i chelatowane żelazo. Brak żelaza w pożywce wyraźnie obniżał ilość powstających zarodków.

SŁOWA KLUCZOWE: Nicotiana tabacum, hodowle tkankowe, embriogeneza pyłku, transformanty $\beta$-glukozydazy, węgiel aktywny. 